University of Nebraska - Lincoln

DigitalCommons@University of Nebraska - Lincoln

Journal for the Advancement of Developing

Economies

Economics Department

2015

Developing Economies by Advancing Entrepreneurship: An Interview with Amaury de Parcevaux

Simone T.A. Phipps

Middle Georgia State University, simone.phipps@mga.edu

Amaury de Parcevaux

Beeleev, Inc.

Follow this and additional works at: https://digitalcommons.unl.edu/jade

Part of the Econometrics Commons, Growth and Development Commons, International Economics Commons, Political Economy Commons, Public Economics Commons, and the Regional Economics Commons

Phipps, Simone T.A. and de Parcevaux, Amaury, "Developing Economies by Advancing Entrepreneurship: An Interview with Amaury de Parcevaux" (2015). Journal for the Advancement of Developing Economies. 29.

https://digitalcommons.unl.edu/jade/29

This Article is brought to you for free and open access by the Economics Department at DigitalCommons@University of Nebraska - Lincoln. It has been accepted for inclusion in Journal for the Advancement of Developing Economies by an authorized administrator of DigitalCommons@University of Nebraska - Lincoln. 


\title{
Developing Economies by Advancing Entrepreneurship: An Interview with Amaury de Parcevaux
}

\author{
Simone T. A. Phipps \\ Middle Georgia State University
}

\begin{abstract}
Amaury de Parcevaux grew up in Paris, France, where his boarding school experience availed him the opportunity to meet a variety of people, and thus helped to open his mind to different cultures. The school was located outside of Paris, and whereas before, most of his interactions occurred with Parisians, he now met and formed relationships with individuals from other areas and realized that "these people are different." It was, as he put it, his "first window to a different world."
\end{abstract}

Later, as an undergraduate student at the European Business School, he capitalized on foreign exchange opportunities, spending six months in London and six months in Germany. He continued to learn from others, again recognizing the benefits gained from his exposure to another way of life. After graduation, he decided to work in the banking industry in Germany, where he stayed for seven years. He explained that he increasingly understood how one could learn from people who were different. In fact, his appreciation for entrepreneurship was first derived from his quest for different ways of thinking.

After Germany, he seized the opportunity to work on Wall Street with Deutsche Bank and remained in the banking industry for another eleven years with big firms such as Morgan Stanley and Citibank, amassing significant experience in wealth management. His transition into more entrepreneurial endeavors began when he moved to a small company that was in the business of commercial real estate. He found that he rather enjoyed that he could be himself, have an impact on his immediate environment, and give and receive instant feedback. He saw the opportunity to truly make a difference as he fulfilled his role in global marketing. After he left, he gained other valuable experience, including experience as a Chief Operating Officer for another small or medium-sized enterprise (SME).

Today, Amaury de Parcevaux is still stationed in New York, along with his Chinese wife from Hawaii and his children, who are involved in a wide array of activities that also expose them to different cultures. He is now the President of Beeleev, a company he co-founded with Hugues Franc, Founder and CEO. Franc and de Parcevaux attended boarding school together in France, and reflect the vision and mission of Beeleev, which aims to build a collaborative business platform for entrepreneurs seeking to grow their business internationally.

Entrepreneurs can benefit from Beeleev via membership. Beeleevers' membership opens a farreaching network that connects entrepreneurs from different countries, providing the necessary contacts to aid entrepreneurs as they conduct business in another country. For example, if an American entrepreneur needs to find a way into the Korean market, membership in Beeleev can 
be an asset. He/she can either directly connect with Korean-based Beeleevers, or request that Beeleev connect him/her with an appropriate profile of Beeleevers, corporate partners, or other experts. Hence, Beeleev is a multi-layered global partnership platform. The organization was started in June 2013 in Paris, expanded into New York in April 2015, and has grown from 400 members in 15 countries in April, to over 1300 members in 164 countries today. There are currently three offices in Paris, New York, and Omaha, but according to de Parcevaux, the expectation is that by 2018 , Beeleev will have 200,000 members, and local operations in at least 40 countries. The organization also strives to benefit communities. Networking events are organized locally, so members can establish personal ties with other members, corporate partners and experts. Beeleevers can also participate in "turn-key cross border learning expeditions," such as the one planned for November 2015, where Beeleevers in the Americas will meet Beeleevers and experts in Hong Kong and Singapore.

One may say that there are already other platforms that help to connect people. However, de Parcevaux asserts that Beeleev is unique as it focuses on cross-border networking, with a platform that is virtual as much as it is personal. It can help business, but it is not solely about business. It is an opportunity to advance entrepreneurship, learn about culture, build bridges between cultures, enhance best practices, and ultimately contribute to developing economies. Interested individuals can complete an application online at www.beeleev.com. Currently, it is free to join. All that is required is that the applicant be qualified by being a CEO, president, founder, or co-founder of an SME. Therefore, the latter can be comprised of a sole proprietor. When membership reaches 2,500 however, a nominal fee may be charged to additional members. Therefore, according to de Parcevaux, "Better Beeleev now!" 